\title{
HISTORY EDUCATION AS AN EDUCATIONAL MEDIUM TO EMBODY THE SPIRIT OF NATIONALITY
}

\author{
Said Hamid Hasan ${ }^{1}$
}

\begin{abstract}
The above objectives of history education clearly indicate that history education aims at the development of students awareness of time concept; scientific knowledge of the society in the past in terms of their values, ways of thinking, attitudes and achievement; skills for understanding and generating knowledge of the past; attitudes towards history as what happened in the past society, and history as a science that reconstruct the past . To put it in a simple way the objectives suggest that students should have knowledge about the past scientifically and this knowledge is gained through the application of historical thinkings and skills. The objectives also suggest that history education should preparestudents for their roles as a citizen who loves and is proud of thecountry, the nation and their past achievement. Further, the objectives place history as an education media for preparing the students for their future lives. Big potential of historical education is developing the nation's identity. Historical education is a vehicle that gives opportunities for young generations to conduct self identification as a member of this nation. History education potential in developing the nation with heroism,leadership, and willingness to sacrifice.
\end{abstract}

Key Word: history education, nationalism, heroism, leadership, willingness to sacrifice

\section{Introduction}

History education is a fairly old content of education Indonesian and many other countries' curriculums. Examination on the development of curriculum in Indonesia shows that history education has become a compulsory subject since the Netherlands and J apanese colonialism and independent era (Hasan, 2010). In the Netherlands colonialism period, Mulo (J unior High School) fell in subject

1 Prof. Dr. Said Hamid Hasan is Professor of History Education, Indonesia University of Education (Universitas Pendidikan Indonesia-UPI). This Article has been reviewed by Prof. Dr Rochiati Wiriatmadja, M.A (Indonesia University of Education, Dr. Nana Supriatna, M.Ed (Indonesia University of Education, and Prof. Dadang Supardan, M.Pd ((Indonesia University of Education. For academic interest, the author can be contacted at eshamidhasan@yahoo.com. 
named Volks geschiedenis and Vaderlanse geschiedenis. In J apanese military period, there was a history subject. Volks geschiedenis dealt with the history of Indonesian from the Netherlands' colonial mindset and Vaderlanse geschiedenis presented the history of Dutchmen in their country to enhance awareness and admittance that the Netherlands is mother country of Indonesian. SR (Elementary School) curriculum in 1947, there was a history subject started from grade IV-VI, in J unior High School there was a history subject classified as Social Science along with Geography (Hasan, 2010) and in Senior High School there was also history subject (Djojonegoro, 1996:101). History education is considered as an important point mentioned in the Regulation of the Minister of National Education number 22 of 2005 that "History subject has strategic value in forming prestigious character and civilization of the nation and in creating Indonesian human resources with the sense of nationality and loyalty to the country".

The potentials of history education in building the sense of nationalism are explicitly mentioned the Regulation of the Minister of National Education number 22 of 2005 on Standardized Contents. Related to history education, it is mentioned that History subject has strategicvaluein forming prestigious character and civilization of thenation and in creating Indonesian human resources with the sense of nationality and loyalty to the country. The contents of history education are:

1. demonstrating the values of heroism, paragon, revolutionary, patriotism, nationalism, and surviving spirit that serveas the basis of creating participants' character and personality;

2. describing resources of the civilization of nations, including the civilization of Indonesian. That content is the basic materials of education for the process of construction and creation of the nation of Indonesia in the future;

3. fostering the awareness of unity and fraternity as well as solidarity to strengthen the nation for dealing with the possibility of disintegration of the nation;

4. full of moral and wise principles useful for solving multidimensional crisis in daily life;

5. useful for fostering, encouraging and developing responsible attitude in maintaining environmental balance and viability.

In other countries, history education is considered as a fairly important part of a curriculum. From NIER document (1999), some countries such as J apan, New Zealand, Sri Lanka, France, China, Fiji, India, Laos, Malaysia, Philippines, South Korea, Thailand, Uzbekistan, and USA insert history education in the curriculum. It is particularly designed as social science "strand", as geography supplement or as an independent subject of History. O'Donnell and his friends' study reveals that history exists in England, Irish, Canadian, Hungarian, Italian, Dutch, Swedish, Singapore, and Spanish curriculums and formulated as a part of social science or an independent subject. Nationalism and "heritage literacy" become the objectives of history education in those countries. 


\section{History Education and Confronted Condition of The Nation}

Reformation granted freedom to politicians, society, and media to talk, to present spoken or written opinions, or actions. Demonstration as an actualized action happens everywhere and almost every time. Moreover, it frequently results in brutal and even harmful actions. Contradiction between government and legislative board or DPR occurs as an issue that may reconstruct the system of power (but does not always deal with the government) arises and it reflects as if those loudly arguing among them should or must become the winner. Exaggerated freedom may lead to destruction, aggression, and other seem-tobe-criminal actions. Printed and electronic mass media with almost unlimited freedom in the name of public interest and press freedom reports contradiction, demonstration, destruction, brutal actions and other negative movements of the nation every day without concerning how they influence the society and the condition of the nation. Freedom also leads to the emergence of terse, positive, productive, and creative thoughts within various scientific and academic forums, or mass media. Unfortunately, contradiction among various elements of powers (executive, legislative, judicative), and overrated manifestations of freedom have taken over the main concerns for maintaining and developing the condition of the nation in education, especially history education.

Damages within the condition of the nation were also resulted from a range of internal factors that increase in quite some times. Corruption, moral decadency, deception, robbing, bypassed mentality, feudalism in bureaucracy, label-oriented behavior, egoism, and other negative behaviors have developed in the life of the nation and harmed the foundations of nationality and nationalism spirit.

The reality in the life of the nation is the fact to deal with by history education. It should take some parts in maintaining a better life for the nation. History education has to modify particularirrelevant traditionsin education within society. Education that produces intellectual human and ignores character education will result in various damages in the society (Theodore Rosevelt). The betterment should be started from history education especially related to the policy of history education and its implementation in elementary level.

\section{Problems of History Education}

The development of education, especially curriculum, in Indonesia is dominated by two visions. Firstly, education in Indonesia is dominated by philosophical outlooks of essentialism and perennialism. Secondly, education in Indonesia is motivated by the consideration that the great and developed nation is the nation mastering sciences and technology. Both become more dominant in reformulating curriculum in Indonesia and it is obviously reflected from the curriculum policy on National Examination (Ujian Negara-UN) and learning materials allocated for each subject. Learning materials interpreted as credit hours (satuan kredit semester-sks) are provided for mathematics and 
science. For regular phases of education (out of phases / streaming) science and mathematics commonly deal with a great number of materials. Mathematics and science education become the priority and are considered as forms of education that will make the life of the nation better. Their success within societies in many countries motivates the issue of the policy for the priority of mathematics and science education.

This consideration is not mistaken as in reality, human must need technology. There is no society that is not affected and supported by technology. It is the fact that technology is resulted from knowledge on things in the universe, on how to process them to give more benefits and functions, on how particular matters can solve others such as metal that can hit softer substances, how to process things in nature to become more valuable items, etc. there is a historical fact that human develops knowledge and technology that become more sophisticated to utilize what is provided by nature to become a masterpiece in forms of buildings, daily life utensils, and others that make this life more beautiful and civilized. However, it is true that human develops knowledge to develop his life in the organization of society that starts from the small and simple one and becomes wider, bigger, and more complex to become a nation. In addition, the truth is also that the new pattern of life gets more complex and more globalized as technology demands for newly competent humans with new perspectives, attitude, ways of thinking, and actions.

One thing that is not commonly realized in making curriculum policy is that it always deals with the improvement of human quality. Human should become the primary concern as he or she develops science, technology, arts, cultures, politics, and so on. The quality of human covers the quality of his or her knowledge, ability and skills to develop him or herself either in school system or out of it, and the values, attitudes, and healthy habits as human does not live free from values, norms and mutual aspiration. Those are manifested in the life of the nation, which becomes nation's identity and uses nationalism as the basis for developing personality of the nation. Nevertheless, the nation that loses its identity means it loses its existence in across-nations circle. Thus, education policy only concerning what to be possessed and ignoring human as who will possess it has strong potential to erase the identity of the nation.

History education is intended to improve the values of human and humanity. The philosophy of perennial education is intended to develop rational thinking by asserting the values of glorious past. History must be related to it and it depicts human's struggle to uphold his or her quality as human and his or her humanity. Through history education, humanity values are constructed in each individual of students as a great framework named as the identity of the nation. The development of human with this framework will be the greatest starting point for the nation to develop, to be able to protect positive national life, to compete, and to contribute in across-nation life. Theimprovement of human and humanity values from historical events can bea strong foundation for developing aspirations of the nation as they are written in Pancasila as the manifestation of nationalism spirit though it has not become the main materials of history education. Materials 
of history education are still focused on knowledge about historical facts. Values derived from historical events should be the focus of material examination of history education, which is developed to as the identity of every citizen as a strong basis for implementing Pancasila in individual, societal, national life. Therefore, Pancasila will be firm for not being frequently mentioned, but for becoming the values of Indonesian's attitude and behavior.

Materials of history education reflect human's life and humanity in the past period of the nation. Historical events are happenings in human life. They portray human's struggle, success, and failure to preserve the identity of the nation. Historical events are not the struggle for one's life, but for the nation's life. Heroes and leaders recorded in historical events are those who live in a community called a nation. Hence, the materials of history education completely describe the journey of life of the nation from its early part before it is constructed, until the life of the nation is manifested, and its journey to develop its identity. Success and failure are dynamic conditions that need to be explored by new generation as a lesson and developed as a better element for the identity of the nation.

The journey of life of Indonesian nation is marked by great efforts and sacrifice. Sacrifice is required as the philosopher of the nation in the early part of $20^{\text {th }}$ century started to think about the existence of a nation in a widespread area but it is still ruled by the Dutch. The sacrifice got stronger day by day and the leaders even dared to manifest their intention by swearing and it is known as Sumpah Pemuda (the vow of youths): the one motherland of Indonesian soil, the one nation of Indonesian nation, and the one language of bahasa Indonesia. Those who actually have their own mother tongue should be willing to release that identity to get the new one named bahasa Indonesia.

The youths were courageous to take the risk. They sacrificed everything they had to get a new nation, a new identity. They struggled to declare the nation and all its newidentity named Indonesia through various methods. Initially, the effort seemed unclear but it was crystallized with the birth of various national parties. The connection of their efforts that previously came from local motivations was blended by the vow and reconnected and no longer became primordially oriented without losing local connection. New organization and new connection became the foundation to fight for the birth of the new nation. This value becomes so important for materials of history education in fostering nationalism.

The climax of the effort was not the same as the final effort of Indonesian nation, to create a new basis for upcoming effort, i.e. declaring the independence. The declaration is the major impulse (or the golden bridge) to construct a new life and aspiration to have a society without any poverty and foolishness, but can take parts in national activities, develop personal interest and wants, and have religious life. The declaration was not something free, but it had to be paid with people's material goods and blood as the nation had to confront the colonialism of the Dutchmen that wanted to rule the country again. The struggle to preserve the independence of the nation cannot be measured by anything except the greatest nationalism. 
Conflict must exist in every story in human life including in the history of the development of nationality in Indonesia. Unfortunately, the interpretation to the conflict frequently seems to be black and white and full vengeance. The colonizers (the Dutch, English, and J apanese) are always described from their dark sides as the source of people's misery, as if there are no good deeds given by them to Indonesian nation. The implementation of Tanam Paksa (Forced Cultivation) is portrayed as a great suffer for Indonesian, but its economical advantage to grow new varieties of plants such as quinine, tea, coffee, etc. is not mentioned. Likewise, it also gives benefits by introducing business activities in big company such as private plantation of tea. Another plus point to foster the spirit of unity and to lead to intention to be united as a nation is not well delivered. Such black and white interpretations should be changed, so that students will not only learn history from its dark or bright sides, but also from various perspectives, and they can express their appreciation for the happenings.

In the struggling period, there were conflicts among local governments and central governments, and this interpretation needs to be continued. Local area is awry and central area has all the truth so that central government has legality for upholding its power over local government with various techniques. $\mathrm{J}$ ustification on central government actions makes positive points and truth from local movements in conflict with the central government unexposed or even ignored as negative actions of central government towards local government are not uncovered.

The official interpretation of national history of Indonesia is also frequently contradicted by black and white interpretation and hatred over past events. The colonizers are considered full of mistakes and the government of Indonesia is always true. As the history of Indonesia was developed and Republik Indonesia Serikat (RIS) appeared, it lasted for a short of time and textbooks have not been rewritten based on the newvision of thenew government so that RIS government's opinion over the previous government of Indonesia was unknown. After RIS was dismissed and the government was reformed as the united nation of Indonesia Republic, the existence of RIS government was considered as the mysterious phase. Indonesian government with its parliamentary system became a picture of success for theyoung structure of state. As the decree was issued and Indonesia was based on The Constitution of 45 (UUD 45), or even as in the era of directed democracy occurred (MANIPOL-USDEK), liberal parliamentary government was considered as a mistake and divergence from aspiration of Indonesian nation.

In the New Order period, former government labeled as the Old Order was considered to be in the black list of the interpretation and the new government (New Order) was in the whitelist. All mistakes of Old Order government were used to become the main reasons for having an aversion to the Old Order. The strong connection between Old Order and Communist made the condition worse. Today, after reformation occurred and becomes dominant and strong within society and government movements, the New Order is disliked and it is not impossible that it will become the topic in history presented next. 
Theattempt to blame past events is strengthened by actions taken by some figures in the past. Some leaders involved in Dutch and J apanese government make some endeavor to clean themselves and to affirm that those past happenings are confronted historical events. Many Old Order leaders call down its actions in which they were involved. Similar fact happened as the New Order was down and Indonesia entered the reformation era. This attitude motivates the composition of textbooks, which has not been able to develop an attitude that those events are parts of life of this nation and it becomes parts of our life today.

Then, how can history education function to erase hostility towards past events and make historical happenings in any periods as part of nation's life? The hostility makes history education lose its power to construct the identity of the nation. Getting across the past of the nation is not the true identity of nation based on Pancasila. Pancasila affirms differences and they need to be respected, and there should be a way to solve the differences. This attempt is the greater identity. Discussion and deliberation becomes the basic principle in constructing the life of the nation in positive senses. History education should lead to an understanding on the principleas a form of cooperation within various movements over historical figures. The Vow of Youths is the key to express cooperation and discussion in maintaining the one nation, motherland, and language from diverse religions, ethnics, and regions. The happening of proclamation is not only aform of cooperation and deliberation amongyoung generation with Bung Karno and Bung Hatta to proclaim the independence of Indonesia, but it is also an agreement from the leaders of the nation to formulate it. The fight in defending the independency was a spontaneous agreement toward the nation's independency, leaders and people with different background and religion. Eliminating seven words from the draft of UUD 1945 was a major agreement between the nation's leaders which then became bigger when the agreement became the nation's agreement.

The weaknesses of History Education along with the fact that History Education has become an education of year, name, actor and course of events. The course of events has been displayed rigidly, thus students have difficulties in obtaining their values and meanings. The leaders' willingness to sacrifice have never been revealed, hence it seems that they fought without values, people, and ideology. When a leader was caught and taken into prison, the situation was poorly described so it seemed that they were no emotions. Regarding these academic matters of not relating the events with emotions has made poor history books along with the teaching and learning process.

When the patriots and people fought together during the revolution, lacking of food, the luxury of taking a bath and losing connection with family and even lover were those which scientifically poor to describe, and hence, were not noted in the history books. The History Lesson Books have lost their humanity aspects because human beings were only considered as names, numbers, and those who carried guns and participated in wars. Hence, it is impossible for students to learn from a poorly described history.

The historical materials, which contain values and moral values, are not the historian interpretation upon historical events or the actors' action. Materials 
categorized as values and moral values in history education are materials related to the philosophy of life, values and moral applied by the actors. The history education that contain values and moral mostly have not described in school textbooks and other related level of education. The stories, which historian and textbooks' writers has reconstructed, has placed the actors as people who undergone the stories with no values and emotions. Hence, it has been the historian and the writers who has decided the course of the stories.

\section{History Education Potential In Developing the Nation}

The potential of a lesson in obtaining its goal is determined by substantial, skill, and values of its materials. Substantial materials such as actors, places and factors of events are learned in order to build knowledge upon historical events. Skills materials are used to develop thinking and learning skills which consist of chronological, causality, critical, analytical, evaluative and creative skills. Learning skills consist of developing questions, searching and identifying data in answering questions, composing the data into facts of historical events and finding causalities upon historical events. Values materials are used to develop behaviors such as leadership, discipline and other valuable features. These three materials are used in the history education.

Historical events are full with heroic actions (J akcson, 2003). Basically, history actors are heroes and leaders for their people and nation. They fought for a better life. Histories of Indonesia people in fighting the invaders were full with ups and downs. The foundation of the efforts is the people love for the nation, so that they are able to have a better life and willing to sacrifice their life in order to obtain the goal. During the invasion, they were willing to life in exile, prison, separation of their nation. During this time, nationalism is viewed as the spirit to be free from invaders.

During the time, the fight was no longer directed toward freedom from invaders but efforts in setting free the people from every aspects of life which were not in line to the cause of the fight. The people and nation have to be free from oppression of human right such the freedom to choose and implement a religion, poverty, illiteracy, freedom to develop personal and communal life and give opportunities to the people in developing the nation's welfare. The leaders and people struggle during the time were multidimensional and not diametric. There were differences between the fight before and during the time, but basically it has similarities which are developing the people welfare, scarifying for the nation and involving the people.

Indeed there are differences between the struggle before and after the independence. However, both of them had the same purpose in terms of providing prosperity of the people, demanding sacrifice from the freedom fighter, and the active involvement from the people. The resistance towards the national government is no longer considered as a heroic act and sitting behind the bar is not the consequence of heroism. 
The act of resistance against the government is not merely black or white anymore, it becomes grey. The appraisal of an act is based on such criteria as obedience of law, economy, social-cultural norms, and also political. Thus, the government political opponent is not always appraised as act of heroism.

Heroism and leadership are no longer belong to the political life or only occurred in a political position. Heroism and leadership occurs in every social dimension. It occurs in economical life, social, culture, arts, sports, science, technology, religious life, agriculture, transportation, and so on. Heroism is not a property of formal leader or position, but it can be distributed to any other individual, equally without any social or status barrier as long as they can contribute positively toward the community. The larger the opportunity dimensions of heroism the bigger the chance of having numerous heroes. By not having social barrier, the chance of future generation in appraising heroism will be greatly improved. The greater number of heroes will give the community a lot of role models and examples so they can develop a better community. Moreover it will inspire more to the younger generations in creating various useful actions for themselves and their community.

Willingness to sacrifice is one major point in heroism and leadership. It is the foundation every heroism and leadership. The willingness to sacrifice becomes the major capitol had by historical figure in struggling for a better nation. However the heroic values, which are the manifestation of nationalism, are often ignored. Historical education often teaches the students just to memorize the historical figures and events.

Experts in history have discussed the way of building nationalism spirit as a potential education for countless times. It can be said that in almost every journal about history education, the experts state that historical education is conducted to build the nationalism spirit and attitude. But in fact, nowadays the historical education is merely just a normative subject, it is stated on the objectives yet there is no real implementation in the teaching process. The history practitioners and learners often just take it for granted; nationalism spirit has been overlapped by students' recitation. In this case, there should be changes in bringing back the position of nationalism value.

Furthermore, Hasan (2008b) wrote about the big potential of historical education in developing thenation's identity. Historical education is a vehiclethat givesopportunitiesforyounggenerationstoconductselfidentificationasamember of this nation. The identification progress is conducted by building collective memory as a nation which becomes a basis in developing nationalism insight and attitude. A failure in building collective memory will cause a disintegration and loss of believe in the nation. Thus, education in history has a prominent role in building collective memory. The education helps recreate and commemorate historical events as a part of the nation's life. The collective memory will be the answer of the self identification. Therefore, Sartono Kartodirdjo (1997:118) stated that the history of the nation is very important to answer "who am I?". in addition, Cartwright (1999:44) stated : "our personal identity is the most important thing we possess, it defines who and what we are. The way we feel about ourselves, the 
way we express ourselves and the way other people see us are all vital elements in the composition of our individual personality".

The value interpretation and inheritance of historical events in Indonesia should become a legacy for the history learners as a member of the nation. A better and a more comprehensive interpretation toward the historical events will accumulatively giveanation collectivememory and historical valueinheritance. In the end, a good appreciation toward values in every historical event will becomea strong base for its self identification. Therefore, the identification process should be applied in the learning process in form of appreciation and comprehension on the nation's historical events. The internalization process of nationalism values will form a citizen with a positive nationalism spirit.

\section{Conclusion}

Historical education is always related to the comprehension of the nation's journey and a powerful media to build nationalism. In the United States, history is massively taught when the country faced identification crisis due to the heavy traffic of immigrants from all across the globe. As a result, the USA government makes social studies which focus on American history, geography and government system as a compulsory lesson to be taught in schools. Both locals and immigrants must learn the lesson because it is important for them to know themselves as a member of the nation.

To become an education media in building nationalism, Historical education should change its curriculum, learning process, teaching materials, and learning results. Historical values should have the same focus as the historical event itself. The values will have the role as an enrichment of the historical knowledge and a combination of pedagogic and academic substance.

In the learning process, historical education should able to give opportunities to the learners to perform not only thinking ability but also internalization process. The historical education must not be a media to hate the past events, but should become a reflection for a better future. The education should be able to give a lesson of the nation success and failure as a step in building the future and solving various problems in today's era.

The assessment of learning result should have enrichment and focus transfer. The assessment toward factual knowledge should be enriched by the in depth comprehension on historical concepts such as events, changes, continuality, nationalism and time concept. The assessment should not ignore other supporting factors such as value, attitude behavior and custom. In addition, Nationalism as a value, attitude and behavior should be set as the enriching focus in historical education starting from the primary level to secondary level. Therefore, we need to develop various assessing instrument and not rely only upon the regular test. 


\section{REFERENCES}

Borries, Bodo von (2000). Methods and Aims of Teaching History in Europe: A Report on Youth and History, dalam Knowing Teaching \&Learning History: National and International Perspectives (Eds. Stearns, P.N., Seixas,P., Wineburg,S.). New York: New York University Press.

Hasan, S.H. (2008a). Pembelajaran Sejarah yang menarik. Disajikan pada workshop pendidikan sejarah di Medan, Direktorat Sejarah Departemen Pariwisata dan Sejarah

Hasan, S.H. (2008b). Pendidikan Sejarah dalam Rangka Pengembangan Memori Kolektif dan J atidiri Bangsa. Tulisan dalam rangka memperingati 100 hari wafatnya Prof. Dr Sartono Kartodirdjo

Hasan, S.H. (2011). Pendidikan Sejarah untuk Membangun Inspirasi dan Mengembangkan Aspirasi. Majalah J urnal Pendidikan Sejarah nomor 2 dalam proses penerbitan

Jakubowski,C. (2002). Teaching World History: Problems and Promises Faced by Young Teachers. World History Bulletin. XVIII, 2.

Koblin, D. (1996). Beyond the Textbook: teaching history using documents and primary sources. Portsmouth, NH: Heinemann.

Levstik,L.S. (2000). Articulating the Silences: Teachers' and Adolescents' Conceptions of Historical Significance, dalam Knowing Teaching and Learning History: National and International Perspectives, Knowing Teaching and Learning History: National and International Perspectives, ed. Stearns,P.N., P. Seixas, dan S. Wineburg.

National Institute for Educational Research (NIER)(1999). An International Comparative Study of School Curriculum. Tokyo

Peraturan Menteri Pendidikan Nasional nomor 22 tahun 2005 tentang Standar Isi IPS dan Sejarah

Wineburg, S. (2001). Historical Thinking and Other Unnatural Acts: Charting the Future of Teaching the Past. Philadelphia: Temple University Press 
SAID HAMID HASAN

History Education as An Educational Medium to embody The Spirit of Nationality 